\title{
CARDIOLOGY
}

Demydenko G.V.

\section{METFORMIN AND LEFT VENTRICULAR HYPERTRO- PHY IN PATIENTS WITH COMORBIDITY}

Kharkiv National Medical University, Ukraine

\begin{abstract}
Essential hypertension (EH) remains an important challenge, due to leading positions in morbidity and mortality not only in Ukraine, but also worldwide. Recent studies have suggested that metformin can inhibit cardiomyocyte apoptosis and improve cardiac function. Aim of the study was to investigate metformin influence on left ventricular structure and function in patients with essential hypertension with concomitant type 2 diabetes (T2D). Materials and methods: the study involved 120 patients with essential hypertension $(\mathrm{EH})$, who were divided into three groups according to comorbid state: 60 patients with EH and T2D; 30 with EH with prediabetes; 30 with EH without dysglycemia. Carbohydrate criteria, left ventricle structure and function were analyzed before and after 12 weeks of metformin treatment. Results. Metformin treatment results in fasting glycaemia and insulin resistance diminished by $21.79 \%$ and $26.84 \%$. Echocardiography in 12 weeks metformin treatment showed a significant decrease in left ventricle myocardium mass by $6.1 \%$ and left ventricle posterior wall thickness by $2.3 \%$. More pronounced changes in patients with EH and T2D were associated with glucotoxicity, lipotoxicity, a decrease in insulin resistance and pleiotropic metformin effects. Conclusion. Metformin has positive influence on the structure and function of left ventricle, increasing EDV and LV hypertrophy regression. These findings may provide a potential effectiveness for patients with T2D at risk of developing pathological cardiac hypertrophy.
\end{abstract}

KeyWords: essential hypertension, type 2 diabetes, left ventricle hypertrophy, metformin.

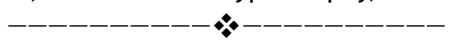

\section{INTRODUCTION}

Essential hypertension (EH) remains an important public challenge, because of its leading positions in morbidity and mortality not only in Ukraine, but also worldwide [1]. Hypertension in obese patients in over $60 \%$ of cases is associated with glucometabolic disturbances, such as insulin resistance and glucose intolerance [2].

Moreover, diabetes develops in $2 \%$ of treated hypertensive patients every year [3, 4]. Pathological left ventricular hypertrophy is a crucial pathological condition that triggers several serious cardiac events, including arrhythmias, heart failure, and sudden death. Recent studies have suggested that metformin can inhibit cardiomyocyte apoptosis and improve cardiac function [5]. However, whether metformin has an inhibitory effect on cardiac hypertrophy hasn't been clarified.

\section{Corresponding Author:}

Demydenko Ganna, PhD, professor of Department of Fundamentals of Internal Medicine N1, Fundamentals of Bioethics and Biosafety of Kharkiv National Medical University. E-mail: demydenkoganna@gmail.com

\subsection{Purpose}

Aim of the study was to investigate metformin's influence on left ventricular structure and function in patients with essential hypertension with concomitant type 2 diabetes (T2D).

\subsection{Subjects \& Methods}

The study involved 60 patients with EH and T2D, who were examined according to National and European Recommendations of T2D Treatment [6, 7]. Metformin was prescribed after titration period in average dosage of 1000 - $2000 \mathrm{mg}$. Comparison group comprised 30 patients with $\mathrm{EH}$ and prediabetes. Also 30 patients with $\mathrm{EH}$ without accompanied dyglycemia were recruited in the study. Antihypertensive treatment was similar in the groups. Taking into account that metformin is not allowed for prescription to the patients with prediabetes, such patients received life style modification recommendations. The results were analyzed before and in 12 weeks treatment period. The aim of antihypertensive treatment was to achieve the level of arterial pressure of $\leq 140 / 85$. Antiglycemc treatment was consideredsuccessful in case of HbA1c level $\leq 7 \%$. 
Inquiring, inspection and laboratory investigations were provided according to the recommendations of Ukrainian Society of Cardiology and ESC/ESH recommendations [8]. The study was approved by local institutional review board committees, and all participants provided written informed consent. All subjects underwent measurements of height, weight at the baseline visit. Body mass index (BMI) was calculated as weight in kilograms divided by the square of the height in meters $(\mathrm{kg} / \mathrm{m} 2)$. Three measurements of systolic blood pressure (SBP) and diastolic blood pressure (DBP) were taken using a standardized sphygmomanometer on the right arm, after a 15-minute rest in a sitting position; the average of the three measurements was used as subject's blood pressure. A blood specimen was collected after overnight fasting into a tube with further centrifuging and freezing for investigations. Carbohydrate metabolism was evaluated on the basis of plasma glucose, insulin, glycated hemoglobin (HbA1c) that were measured both at fasting, and after 120 min of standard glucose tolerance test (OGTT). For insulin measurements the laboratory set DRG ${ }^{8}$ Insulin (DRG Instruments $\mathrm{GmbH}$, Germany, Marburg) was used.

Echocardiography was rendered to all the patients. $M-i$ B-regimens of echolocation according to Ukrainian and European recommendations were used to estimate the structure and function of the left ventricle. [9]

Statistical representation of the results is mean and standard error of mean $(\mathrm{M} \pm \mathrm{SE})$. The difference between groups was calculated using Kruskal-Wallis test. A p value of less than 0.05 was considered to be statistically significant.

\section{Conflict of interests}

There is no conflict of interests.

\section{RESULTS AND DISCUSSION}

Last decade showed many cardiovascular effects of metformin, which seemed significant in prophylaxis and control of cardiovascular diseases. First UKPDS study showed a $36 \%$ decrease in all deaths, $42 \%$ in T2D, a $39 \%$ decrease in myocardial infarction lethality and $41 \%$ in stroke [10].

Scientific data suggest that cardioprotective effects of metformin are associated with lipid the enhancement of metabolism, improvement of endothelial function and vessel reactivity, control of hemostatic disorders [11 - 13].

As previously shown in our study, metformin treatment resulted in a decrease in fasting glycemia and insulin resistance by $21.79 \%$ and $26.84 \%$ and reduction in abdominal fat deposition by $5.54 \%$. Improvement of endothelial function in metformin treatment was associated with an increase in endothelial nitric oxide synthase by $8.43 \%$, a decrease in inducible nitric oxide synthase by $20.62 \%$, with nitric oxide bioavalibility enhancement by $36.6 \%$ by decreasing S-nitrozothiol level. Twelve weeks of metformin treatment showed a positive trend not only in carbohydrate and lipid parameters with insulin sensitivity and endothelial function improvement, but it also resulted in an increase in apelin level by $33.3 \%$, attenuating of vascular endothelial growth factor by $22.0 \%$, a decrease in oncostatin $M$ and interleukin- 6 by $18 \%$ and $15 \%$, respectively. $[14,15]$. Therefore, assessing the obtained data, we are looking for metformin impact on LV. Table 1 presents criteria of LV structure and function according to dysglycemia level. Linear sizes were found to increase in patients with $\mathrm{EH}$ and comorbid state as compared to patients with $\mathrm{EH}$ without dysglycemia. LV myocardial wall thickness and LV myocardial mass were significantly higher in case of $\mathrm{EH}$ and T2D comorbidity.

Table 1.

Left ventricle structure and function criteria in patients with EH according to comorbid state, $\mathrm{Me} \pm \mathrm{SE}$.

\begin{tabular}{|l|c|c|c|c|}
\hline Group & $\begin{array}{c}\text { Patients } \\
\text { with EH }\end{array}$ & $\begin{array}{c}\text { Patients } \\
\text { with EH } \\
\text { and predi- } \\
\text { abetes }\end{array}$ & $\begin{array}{l}\text { Patients } \\
\text { with EH } \\
\text { and T2D }\end{array}$ & $\begin{array}{l}\text { P (Krus- } \\
\text { kal- } \\
\text { Wallis } \\
\text { ANOVA) }\end{array}$ \\
\hline EDS, cm & $4.86 \pm 0.05$ & $5.05 \pm 0.07$ & $4.91 \pm 0.07$ & $>0.05$ \\
\hline ESS, cm & $3.08 \pm 0.05$ & $3.30 \pm 0.05$ & $3.14 \pm 0.06$ & $>0.05$ \\
\hline EDV, ml & $112.21 \pm 2.8$ & $122.44 \pm 4.3$ & $115.70 \pm 3.8$ & $>0.05$ \\
\hline ESV, ml & $38.39 \pm 1.48$ & $45.96 \pm 3.37$ & $40.82 \pm 2.08$ & $>0.05$ \\
\hline PWT, cm & $1.14 \pm 0.01$ & $1.12 \pm 0.02$ & $1.18 \pm 0.02$ & $<0.05$ \\
\hline LVMM, gr & $214.51 \pm 6$. & $213.44 \pm 8.4$ & $224.96 \pm 8.8$ & $<0.05$ \\
\hline
\end{tabular}

EDS - end-diastolic size; ESS - end-systolic size; EDV - enddiastolic volume; ESV - end-systolic volume; PWT - posterior wall thickness; LVMM - left ventricle myocardial mass

Echocardiography in 12 weeks of metformin treatment (Table 2) showed a significant decrease in LVMM by $6.1 \%$, LVT by $2.3 \%$. Patients with EH with concomitant prediabetes and without comorbidity were not shown to have significant differences in LV EDV, PWT, LVMM. More pronounced 
changes in patients with EH and T2D were associated with glucotoxicity, lipotoxicity, a decrease in insulin resistance and pleiotropic metformin effects [16].

Table 2

LV structure and function parameters in patients with $\mathrm{EH}$ and T2D after 12 weeks metformin treatment, as compared to patients with $\mathrm{EH}$ and prediabetes and ones without comorbid state.

\begin{tabular}{|c|c|c|c|c|c|c|}
\hline $\begin{array}{l}\text { Parameter } \\
\text { Group }\end{array}$ & $\begin{array}{c}\text { EDS, } \\
\mathrm{cm}\end{array}$ & $\begin{array}{l}\text { ESS, } \\
\mathrm{cm}\end{array}$ & $\begin{array}{c}\text { EDV, } \\
\mathrm{ml}\end{array}$ & $\begin{array}{l}\text { ESV, } \\
\mathrm{ml}\end{array}$ & $\begin{array}{l}\text { PWT, } \\
\mathrm{cm}\end{array}$ & $\begin{array}{l}\text { LVMM, } \\
\text { g }\end{array}$ \\
\hline $\begin{array}{l}\text { Patients } \\
\text { with EH }\end{array}$ & $\begin{array}{l}4.66 \pm \\
0.05\end{array}$ & $\begin{array}{l}3.04 \pm \\
0.05\end{array}$ & $\begin{array}{r}109.9 \\
\pm 1.95\end{array}$ & $\begin{array}{l}37.92 \\
\pm 2.02\end{array}$ & $\begin{array}{l}1.11 \pm \\
0.02\end{array}$ & $\begin{array}{l}211.21 \\
\pm 5.85\end{array}$ \\
\hline $\begin{array}{l}\text { Patients } \\
\text { with EH and } \\
\text { prediabetes }\end{array}$ & $\begin{array}{l}5.01 \pm \\
0.02\end{array}$ & $\begin{array}{l}3.25 \pm \\
0.05\end{array}$ & $\begin{array}{l}120.9 \\
\pm 3.12\end{array}$ & $\begin{array}{r}45.06 \\
\pm 2.65\end{array}$ & $\begin{array}{l}1.11 \pm \\
0.02\end{array}$ & $\begin{array}{l}210.30 \\
\pm 6.02\end{array}$ \\
\hline $\begin{array}{l}\text { Patients } \\
\text { with EH and } \\
\text { T2D }\end{array}$ & $\begin{array}{l}4.78 \pm \\
0.05\end{array}$ & $\begin{array}{l}3.10 \pm \\
0.02\end{array}$ & $\begin{array}{r}112.8 \\
\pm 2.65^{*}\end{array}$ & $\begin{array}{l}40.78 \\
\pm 2.01\end{array}$ & $\begin{array}{l}1.15 \pm \\
0.02^{*}\end{array}$ & $\begin{array}{l}211.46 \\
\pm 5.41^{*}\end{array}$ \\
\hline $\begin{array}{l}p \quad \text { (Kruskal- } \\
\text { Wallis } \\
\text { ANOVA) }\end{array}$ & $>0.05$ & $>0.05$ & $<0.05$ & $>0.05$ & $>0.05$ & $<0.05$ \\
\hline
\end{tabular}

*- $p<0.001$ (Wilcoxon test), comparing to data before treatment; EDS - end-diastolic size; ESS - end-systolic size; EDV end-diastolic volume; ESV - end-systolic volume; PWT - posterior wall thickness; LVMM - left ventricle myocardial mass

The MET-REMODEL, a double blind, randomized, placebo-controlled trial showed that metformin was effective in regression of the independent cardiac risk factor of $\mathrm{LVH}$ in insulin resistant patients with CAD. Positive result may help clinicians identify a new mechanism for LV regression by administering metformin. This may also lead to investigating the mortality benefit of Metformin in patients with CAD and LVH [17].

Metformin is known as an activator of AMP-activated protein kinase (AMPK). Zhang C.X. et al. used cultured cardiomyocytes to examine the effects of metformin on the AMPK-endothelial NO synthase (eNOS) pathway. The findings of the study indicated that long-term treatment with metformin could attenuate ventricular hypertrophy induced by pressure overload via activation of AMPK and a downstream signalling pathway involving eNOS-NO [18]

The investigation of the Yong-nan Fu revealed that longterm administration of metformin may attenuate cardiac hypertrophy induced by pressure overload in nondiabetic mice, and this attenuation is highly dependent on AMPK activation. [19]

Therefore, we speculate that metformin has positive in- fluence on the structure and function of left ventricle with increasing of EDV and LV hypertrophy regress.

\section{CONCLUSIONS}

Pleiotropic effects of metformin resulted in LV hypertrophy regression by $6.1 \%$ in LVMM, and $2.3 \%$ in LV PWT in patients with EH and T2D. These findings may provide a potential effectiveness for patients with T2D at risk of developing pathological cardiac hypertrophy.

\section{REFERENCES}

1. Kovalenko V. M., Kornatskyi V. M. (2014). Khvoroby systemy krovoobihy yak medycho-sotcialna I suspilnopolitychna problema [Blood circulation system diseases as medical-social and political problem]. Analytical-statistical manual. Kyiv, $280 \mathrm{p}$.

2. Demydenko G. V. (2015). Imunozapalennya, endotelialna dysfynchtsia yak fachtory vysokoho kardiometabolichnogo rysyky u chvorych na hipertonichny chovorobu z dysglichemiyeu [Immune inflammation, endothelial dysfunction as factors of high cardiomethabolic risk in patients with essential hypertension with dysglicemia]. Science rise, 10/3 (15), 20-25. DOI: 10.15587/2313-8416.2015.51655.

3. Palavra F., Reis F., Marado D., Sena A. (2015). Biomarkers of Cardiometabolic Risk, Inflammation and Disease. Springer International Publishing, Switzerland, 165 p.

4. Wei C., Ranson L., Davidson L. et al. (2014). Metabolically healthy severe obesity and cardiovascular disease risk: a 6-year longitudinal prospective study. J. Am. Coll. Cardiol, 63(12_S). Doi : 10.1016/S07351097(14)61353-X.

5. Davis B.J., Xie Z., Viollet B., Zou M. H. (2006). Activation of the AMP-activated kinase by antidiabetes drug metformin stimulates nitric oxide synthesis in vivo by promoting the association of heat shock protein 90 and endothelial nitric oxide synthase. Diabetes, 55 (2), 496500.

6. Order of Ministry of health of Ukraine № 1118 from 21. 12. 2012.

https://www.moz.gov.ua/ua/portal/dn_20121221_1118.ht 
$\mathrm{ml}$.

7. Rydén L. et al. (2007) Guidelines on diabetes, prediabetes, and cardiovascular diseases: executive summary. The Task Force on Diabetes and Cardiovascular Diseases of the European Society of Cardiology (ESC) and of the European Association for the Study of Diabetes (EASD). Eur. Heart. J., 28, 88-136.

8. Mancia G., Laurent S., Agabiti-Rosei E. (2009) Reappraisal of European guidelines on hypertension management : a European Society of Hypertension Task Force document. J. Hypertension, 27, 2121-2158.

9. Lang R. M., Bierig M., Devereux R. B., Flachskampf F. A., Foster E., and Stewart W. (2006) Recommendations for chamber quantification. Eur. J. Echocardiography, 7, 79-108.

10. Zhou K., Bellenguez C., Spencer C. C. (2011) GoDARTS and UKPDS Diabetes Pharmacogenetics Study Group, Wellcome Trust Case Control Consortium 2, MAGIC Investigators. Common variants near ATM are associated with glycemic response to metformin in type 2 diabetes. Nat. Genet, 43, 117-120.

11. Pawlyk A. C., Giacomini K. M., McKeon C., Shuldiner A. R. and Florez J. C. (2014) Metformin Pharmacogenomics: Current Status and Future Directions. Diabetes, 63(8), 2590-2599. Doi : 10.2337/db13-1367.

12. Sussman J. B., Kent D. M., Nelson J. P., Hayward R. A. (2015) Improving diabetes prevention with benefit based tailored treatment: risk based reanalysis of Diabetes Prevention Program. BMJ, 350, 454. Doi : 10.1136/bmj.h454.

13. Kumar R., Kerins D. M., Walther T. (2015) Cardiovascular safety of anti-diabetic drugs. European Heart Journal. Cardiovascular Pharmacotherapy, 202-208. Doi : 10.1093/ehjcvp/pvv035/.

14. Kovalyova O. M., Demydenko G. V., Ambrosova T. V. (2012). Terapevtychnyi potentsial metforminu: vpliv na vuglevodnyi profil ta vasoactyvnyi pul oksidy azoty u chvorych iz poyednanoyu patologiyeyu [Therapeutical potency of metformin: influence on carbohydrate profile and vasoactive nitric oxide pool in patients with comorbidity]. Problems of endocrine pathology, 4, 57-64.

15. Kovalyova O. M., Demydenko G. V., Ambrosova T. V. (2012). Terapevtychnyi potentsial metforminu: vpliv na vuglevodnyi, lipidnyi, tsytokinovyi profil u chvorych iz poyednanoyu patologiyeyu [Therapeutical potency of metformin: influence on carbohydrate, lipid, cytokine profile in patients with comorbidity]. Problems of endocrine pathology, 3, 35-43.

16. Inzucchi S. E., Bergenstal R. M., Buse J. B., Diamant M., Ferrannini E., and Matthews D. R. (2015) Management of Hyperglycemia in Type 2 Diabetes: A Patient-Centered Approach: Update to a Position Statement of the American Diabetes Association and the European Association for the Study of Diabetes. Diabetes Care, 38(1), 140-149. Doi : 10.2337/dc14-2441.

17. Mohan M., McSwiggan S., Baig F., Rutherford L. and Lang C.C. (2015). Metformin and its effects on myocardial dimension and left ventricular hypertrophy in normotensive patients with coronary heart disease (the MET-REMODEL study): rationale and design of the METREMODEL study. Cardiovasc Ther, 33(1), 1-8. doi: 10.1111/1755-5922.12101.

18. Zhang C.X., Pan S.N., Meng R.S., Peng C.Q., Xiong Z.J. and Dong Y.G. (2011). Metformin attenuates ventricular hypertrophy by activating the AMP-activated protein kinase-endothelial nitric oxide synthase pathway in rats. Clin Exp Pharmacol Physiol, 38(1), 55-62. doi: 10.1111/j.1440-1681.2010.05461.x.

19. Yong-nan Fu, Han Xiao, Xiao-wei Ma, Sheng-yang Jiang, Ming $\mathrm{Xu}$ and You-yi Zhang (2011). Metformin attenuates pressure overload-induced cardiac hypertrophy via AMPK activation. Acta Pharmacologica Sinica, 32, 879887. doi: 10.1038/aps.2010.229.

Received: 23-Mar. - 2017

Accepted: 23-Jun. - 2017 